\title{
ENDOPHYTES, AS PROMOTORS OF in vitro PLANT GROWTH
} (review)

\section{L.S. SAMARINA, V.I. MALYAROVSKAYA, E.V. ROGOZHINA, L.S. MALYUKOVA}

All-Russian Research Institute of Floriculture and Subtropical Crops, Federal Agency of Scientific Organizations, 2/28, ul. Yana Fabritsiusa, Sochi, 354002 Russia, e-mail bfbr@vniisubtrop.ru, MalukovaLS@mail.ru, samarinalidia@gmail.com (corresponding author)

ORCID: Malyukova L.S. orcid.org/0000-0002-0500-1198

The author declares no conflict of interests

Received June 29, 2017

\section{Abstract}

In vitro plant propagation is a developed biotechnology, however until now there are no effective protocols for many perennials, especially for trees. High contamination of mature explants during tissue culture initiation, low multiplication and rooting during following passages are the main challenges. Aseptic culture of explants is associated with stress due to tissue damage and exposition to aggressive disinfectants and antibiotics during initiation. These could be the reasons of virulence of endophytes in following propagation. Plant-associated microorganisms were until recently seen as a problem for micropropagation, leading to contamination of in vitro explants. However recent studies showed that colonization of endophytes often play crucial role for increasing viability of in vitro and ex vitro plants. Most endophytes affect positively plant growth, providing nutrients and exhibiting antagonism to pathogens, as well as decreasing stress effects on plants. Beneficial effects were obtained in using Beauveria bassiana (J. Akello et al., 2007), Piriformospora indica and other members of family Sebacinales (P. Sharma et al., 2014), Fusarium oxysporum (A.S.Y. Ting et al., 2008), Ophistoma-like fungi (M. Mucciarelli et al., 2003), Phialocephala fortinii (M. Vohnik et al., 2003), Trichoderma harzianum and other Trichoderma species (P. Franken et al., 2012). Of bacteria, Acetobacter diazotrophicus (C.O. Azlin et al., 2007), Achromobacter xylosoxidans (A. Benson et al., 2014), Azospirillum brasilense (E.E. Larraburu et al., 2015), Azotobacter chroococcum (E.E. Larraburu et al., 2007), Bacillus subtilis (M. Vestberg et al., 2004), B. megaterium (P. Trivedi et al., 2007), Burkholderia phytofirmans (E.A. Ait Barka et al., 2000), B. vietnamiensis (M. Govindarajan et al., 2006), Enterobacter sp. (M.S. Mirza et al., 2001), Klebsiella variicola (C.-Y. Wei et al., 2014), Microbacterium sp. (M. Quambusch et al., 2014), Pseudomonas fluorescens (J. Thomas et al., 2010) и P. putida (R. Lifshitz et al., 1987) also can beneficially influence plants. But until now it is unclear which factor is a trigger switched endophytes from mutualism to virulence. The only way to control such a change is to develop optimal conditions (time of obtaining explants, culture media composition and $\mathrm{pH}$, temperature, etc.) in view to save in vitro mutualism with benefit for both host plant and the endophyte. Studies of many perennials showed the in vitro biotization to be helpful in microclonal propagation and plant rooting. Particularly, arbuscular micorhyza, ectomicorhyzal fungi, ericoid micorhyzal fungi, and wide range of bacteria influence positively plant micropropagation. Bacterial and fungal endophytes could stimulate plant growth due to activation of plant protection mechanisms, induction of systemic resistance to pathogens, phytohormone synthesis and better transport of water and nutrients. In this, the difficulties of classification and obtaining pure cultures of microorganisms are the main problems faced with. hormones

Keywords: micropropagation, endophyte, plant culture media, growth regulators, phyto-

In vitro plant propagation is a developed field of biotechnology; however, until now there are no effective protocols for many perennials, especially for trees $[1,2]$. Low yield of aseptic explants for tissue culture, low multiplication and rooting of microshoots during passages are the main challenges. Surface sterilization of explants and treatment with antibiotics do not relieve plant tissues from endophytic microflora, but often provoke the virulence of latent microorganisms [3]. In the culture, bacteria and fungi may appear in the first or, what happens more often, after a few passages (the so-called secondary infection) [4- 
6]. Moreover, even in the absence of visible traces of microorganisms in the explant culture the efficiency of multiplication and rooting of the perennial microshoots is often low [7, 8] which can also result from a misbalance of endophyte bacterial communities [3].

Endophytic microorganisms contribute to growth and development of the host plant through production of phytohormones, better transport of water and nutrients, activation of biological protection mechanisms and induction of systemic resistance to phytopathogens [9].

The metabolic activity and the nature of the plant cell wall play a key role in the colonization of the host plant by microorganisms [10]. At different stages of colonization, the plant innate immunity is suppressed by phytohormonal signaling, which leads to better compatibility between the endophyte and the plant [11]. According to the latest data, plants and microorganisms coevolve, and, probably, even in "aseptic" in vitro tissue culture, there is no plant free from microorganisms $[12,13]$.

This data has been confirmed in numerous works, including in our studies, which mark visually the appearance of microorganisms in aseptic Pelargonium, Citrus spp., Camellia sinensis, Hydrangea macrophylla cultures and many other perennial species in multiple subcultivation $[14,15]$ The localization of microorganisms in the host plant is different: they occur in the apoplast, the intercellular spaces, the lumen of differentiated dead cells (sclerenchyma and xylem cells) of organs (roots, branches, leaves, flowers, fruits and seeds) and very rarely inside the cell [16].

The first reviews related to the application of microorganisms in cultures of in vitro plant tissues were published by J. Novak [17] and M.K. Rai [18]. J. Novak coined the term "biotization" and summed up the positive examples of its use in the plant micropropagation. The second article gives examples of mycorrhization in cultivated in vitro plants, deals with the problems of finding strains, obtaining a pure culture and the possibility of using mixed fungal cultures. The recently published review of the Russian colleagues focuses on identification and classification of bacterial microorganisms, their possible role in the culture of in vitro explants [5]. After that, the reviews on the positive results of the bacterial and fungal endophytes use in multiplication of in vitro plants have not been published. Filling the gap, we have summarized the progress made in recent years in biotization of in vitro plant cultures by fungal and bacterial microorganisms, and have identified promising areas of research in this field. In addition, in our review we briefly touch upon mechanisms to foster plant growth and defense reactions with the help of endophytic microorganisms.

Biostimulation and bioprotective potential of in vitro microorganisms. For plant micropropagation, the researchers used a wide range of microorganisms, fungi and bacteria. They evaluated the effect of arbuscular mycorrhiza [19], ectomycorrhizal fungi [18] and ericoid mycorrhizal fungi [20]. Beneficial effects were obtained in using Beauveria bassiana [21], Piriformospora indica and other members of family Sebacinales [22], Fusarium oxysporum [23], Ophiostoma-like species of fungi [24], Phialocephala fortinii [25], Trichoderma harzianum and other Trichoderma species [26]. A meta-analysis of the influence of root fungal endophytes showed that woody plants generally respond negatively to their presence, while herbaceous monocotyledons often respond positively to inoculation [27]. Of bacteria, Acetobacter diazotrophicus [28], Achromobacter xylosoxidans [29], Azospirillum brasilense [30], Azotobacter chroococcum [31], Bacillus subtilis [32], B. megaterium [33], Burkholderia phytofirmans [34], B. vietnamiensis [35], Enterobacter sp. [36], Klebsiella variicola [37], Microbacterium sp. [38], Pseudomonas fluorescens [39] and P. putida [40] were studied. Bacterial in- 
oculation resulted in increased fresh and dry weight of shoots and roots, plant height, leaf area and rhizome mass [19, 20], better in vitro rooting (number and length of roots) [30], best adaptation (the percentage of acclimatization, the appearance of the plant) [41], early flowering and increased number of flowers, increased resistance to stress and immunity [42]; moreover, there were differences in profiles of metabolites [43].

The beneficial impact of microorganisms on the growth and biomass accumulation is due to the improvement of nutrient absorption by plant tissues and the production of various secondary metabolites, growth regulators [45], chitinolytic enzymes involved in protection against pathogens [46] and osmoprotectants, by which plants overcome abiotic stresses [47]. Below, some mechanisms and examples of biostimulation will be discussed in more detail.

Plant growth can be improved directly due to secondary metabolites and phytohormones produced by the microbial endophyte cell. For example, Streptomyces atrovirens ASU14 uses tryptophan and synthesizes indoleacetic acid IAA (22 rg/ml) [47]. Auxin-like activity was also observed in pteridic acid, which is synthesized by $S$. hygroscopicus TP-A0451 - endophyte of Pteridium aquilinum plant (L.) Kuhn ex Decken (Commom Bracken Fern) [48]. This substance stimulates the elongation of roots and the formation of adventitious roots in hypocotyls of Phaseolus vulgaris pinto bean. Another class of compounds produced by certain endophytes is gibberellins [49]. Strong growth stimulating influence of many endophytes is also due to the fact that they can turn plant exudates and macromolecules into forms digestible by other growth stimulating microorganisms, which is one of the mechanisms of plant growth biostimulation [50].

Microcuttings of Pinus pinaster Sol. and P. sylvestris L. pines rooted more effectively in the processing by Hebeloma cylindrosporum Romagnesi strains [51], and spontaneous rhizogenesis of Larix eurolepis larch microcuttings obtained from somatic embryos increased significantly in the presence of four ectomycorrhizal fungi, while the length and the degree of root branching increased [52]. Another study shows the influence of Achromobacter xylosoxidans AUM54 and indolyl-3-butyric acid (IBA) on the growth of in vitro Naravelia zeylanica (L.) DC medicinal plant. A. xylosoxidans is a diazotrophic endophytic bacterium, which showed a pronounced ability to enhance the uptake of $\mathrm{NO}_{3}^{-}$by roots and reduce the content of ethylene (presumably due to the production of deaminases) [53]. Plant processing by these endophytic bacteria in combination with IBA improved the growth of shoots propagated in vitro, increased the length and the number of roots, the content of chlorophyll, nitrogen, antioxidant enzymes (peroxidase and superoxide dismutase) and enhanced resistance to stress (ethylene level) compared to the indicators in the untreated control. In the separate application of bacteria and IBA, a positive effect was much weaker [29]. In case of in vitro plant inoculation of Elaeis guineensis Jacq oil palm with Acetobacter diazotrophicus and Azospirillum brasilense diazotrophic rhizobacteria, there was strengthening of roots and shoot growth through fixing atmospheric nitrogen [28]. A. brasilense was more effective than A diazotrophicus. Inoculation of micropropagated Handroanthus impetiginosus (Mart. ex DC.) Mattos plants with A. brasilense strains of $\mathrm{Cd}$ and Az39 stimulated in vitro rooting, reducing the need for auxin by $49 \%$ on MSG half medium [30]. On this medium, Cd strain in combination with IBA $(30 \mu \mathrm{M})$ induced root formation in $98 \%$ of the shoots 21 days earlier than in the control without inoculation. The biomass index of inoculated shoots increased from 127 to $286 \%$.

Plant inoculation with endophytic microorganisms influenced positively not only the root formation, but the increase of in vitro plant biomass, the multiplication coefficient and the synthesis of biologically active substances. Thus, 
subtracting nitrogen-fixing bacteria from sugar beet and their positive impact on the growth of micropropagated plants was described [36]. Two nitrogen-fixing bacterial isolates (SC11 and SC20; $10^{6} \mathrm{CFU} / \mathrm{g}$ of dry weight) were obtained from shoots and two ones (SR12 and SR13; $10^{7} \mathrm{CFU} / \mathrm{g}$ of dry weight) - from roots of plants in the open ground. Isolates identified as Enterobacter sp. produced IBA in pure cultures, and its synthesis increased on a nutrient medium with tryptophan. These isolates were used for inoculation of micropropagated plants. The maximum increase in the weight of roots and shoots and the most active nitrogen fixation were observed in case of SC20 strain. In the study of in vitro growth and the terpene synthesis, Mentha piperita peppermint in response to the inoculation of leaves with fungal endophytes had an increasing plant growth, increased leaf area, dry matter content, root biomass and higher menthol content [24].

Non-pathogenic strains of Paenibacillus glucanolyticus, Curtobacterium pusillum and Methylobacterium extorquens bacteria were isolated from the tissue culture of hosta and raspberry plants [54]. With these bacteria, the microshoots of chrysanthemum Chrysanthemum $\times$ hortorum, gerbera Gerbera jamesonii, hosta Hosta japonica and rose Rosa sp. were inoculated. C. pusillum bacteria stimulated the formation of lateral shoots in all studied genotypes. In the inoculation of $M$. extorquens, the number and the length of shoots and roots of gerbera and hosta, and the number of shoots of chrysanthemum were higher; the length of shoots of chrysanthemum and rose and the length of roots of rose were lower than in the noninoculated control. P. glucanolyticus affected the number and the length of shoots of chrysanthemum and gerbera, but the number of roots of gerbera and hosta was lower than in the control without inoculation; the length of roots of rose was just $0.2 \mathrm{~cm}$. All three bacteria strains assimilated atmospheric nitrogen, and $M$. extorquens and $P$. glucanolyticus also synthesized IBA.

Biofertilization with microorganisms increases the vitality of multiplied in vitro plants at the stage of ex vitro acclimatization. For example, in studies of Czech scientists [20] from the roots of several host plants belonging to Ericales (Vaccinium sp., Calluna sp., Rhododendron sp., Empetrum sp., etc.) row, over 200 strains of endophytic fungi have been allocated. In these experiments, $10 \%$ of the identified strains proved to be effective and influenced positively the growth of micropropagated plants of rhododendron species (Rhododendron sp.) during ex vitro acclimatization in peat substrate. None of the isolates had a negative effect on the growth of host plants. In another study [55], in the optimization of a scheme for in vitro production propagation of wild indigo Baptisia tinctoria medicinal plant, it was shown that the application of arbuscular mycorrhizal fungi increased the acclimatization percentage of microshoots and rooted microplants.

So, according to the research results, cocultivation of plant microshoots and endophytic microorganisms may be an effective method of overcoming the difficulties encountered in some species during in vitro micropropagation.

Bioprotective activity of endophytes. The study of the potential of Pseudomonas sp. PsJN rhizobacteria strain as growth promoters and an increase in resistance of Vitis vinifera L. grape to gray rot caused by Botrytis cinerea showed that inoculation leads to a significant increase in plant growth, making them more resistant and viable [56]. The observed effect enhanced in transplantation. Cocultivation with $B$. cinerea led to significant differences in the pathogen aggressiveness of inoculated and intact plants. In the presence of the studied strain, the plants became more resistant to the pathogen.

Another good example of bioprotective potential of endophytes is the banana tissue culture [42]. One of the most serious banana viral diseases is 
caused by Banana bunchy top virus (BBTV). The treatment of in vitro banana microplants by Pseudomonas fluorescens and Bacillus sp. microbial inocula isolated from the banana roots increased the resistance of plants to biotic and abiotic stresses. For this, the micropropagated banana plants were inoculated with Pseudomonas fluorescens Pf1 and CHA0 strains in combination with EPB5 and EPB22 (Pf1 + CHA0EP + B5 + EPB22) endophytic bacterial strains, which limited significantly the development of BBTV infection in the field (the frequency of contamination was $33.33 \%$, or by $60 \%$ less than in the control). Production of protective enzymes and proteins was greater, and morphological and physiological characteristics were better in the plants treated with rhizospheric and endophytic bacteria (in particular, the plants responded to treatment with increased growth). In this report, induction of systemic resistance in banana with the help of associated bacteria was demonstrated, which may have practical importance for the development of methods for culture banana protection against BBTV virus [42].

Some authors have noted that the systemic bioprotective effect depends on the degree of tissue colonization by the microbiota [57]. Thus, in wheat, the observed antagonism of endophytes against pathogenic microflora was more a consequence of the protection mechanisms activation in the host plant, but not the result of direct antagonistic relations in the microbiota [58]. In experiments to study the effect of Neotyphodium lolii endophytic fungus on the induction of specific protection mechanisms, the inhabited plants were much less susceptible to Fusarium poae infection. In perennial grasses inhabited by endophytes, the number of chitinases is significantly higher than in intact plants, and depends on the time of inoculation [59].

Some endophytes can affect positively the resistance of plants to adverse abiotic factors [60]. Thus, mycorrhizal fungi improve the sodium neutralization under salt stress [61], which may serve as a mechanism for increasing the tolerance of plants in salinization. A similar technique is used in tissue culture to enhance the plant adaptability to abiotic stress (particularly, to salt one), and some endophytes are considered as useful and effective tools [62].

Achievements and problems of identification and use of endophytes in biotechnology. The development of modern methods of microscopy and molecular technologies (e.g., omics technologies) enabled a deeper understanding of interaction in the system of plant - endophytic microorganisms, mechanisms of mutualism and pathogenicity, which is clearly shown by P.R. Hardoim et al. [63], ecologically and evolutionary justifying the term "microbial endophytes". Sequencing of DNA and RNA has radically changed the approach to the study of microbial communities [64, 65]. The result of the application of these methods has received a lot of new data on the plantassociated microorganisms [66]; however, there is a problem with the interpretation and the analysis of this huge volume of genetic information for its effective use [67]. Full sequencing of the endophytic metagenome remains a challenge, as it requires separation of the genome of host plant from metagenome of endophytes [68]. A relatively easy technique is the analysis of the composition of endophytic microbial communities using polymerase chain reaction (PCR) enabling to determine the taxonomic composition of such a community and its structure [69], which, in turn, may reflect functional modifications in the groups of microorganisms [70].

As an example, we present a study of endophytic bacterial communities of six Prunus avium L. genotypes differing in the growth pattern during in vitro micropropagation [38]. For the analysis of uncultivated fractions of endophytic bacteria, a clone library of amplified 16S rDNA fragments was compiled. The 
bacterial diversity was investigated using the analysis of restriction fragment length (restriction fragment length polymorphism - RFLP) in ribosomal DNA with clone sequencing for each certain taxonomic unit. For this purpose, $799 \mathrm{f}$ and 1492r-Y primers were used to separate amplified 16S rDNA fragments. The purified PCR products were cloned into pJet1.2 vector and were transferred into Escherichia coli DH10B. E. coli ampicillin resistant colonies were selected and tested in PCR using HpaII, HhaI, and BsuRI restriction enzymes. In the result, the dominant group of endophytes proved to be Mycobacterium sp. mycobacteria identified in clone libraries from all analyzed genotypes of Prunus genus. Other dominant bacterial groups of easily propagated genotypes were Rhodopseudomonas sp. and Microbacterium sp. The structure of the endophytic communities differed largely from the easily and hardly propagated in vitro genotypes: in the first one, bacteria groups were identified that stimulate plant growth.

As for the industrial use of endophytes in biotechnology and production of medicines-bioinoculants, the main problem is to find the most effective strain or a combination of strains. Over $80 \%$ of endophytes are not detected in seeding on conventional nutrient media [71], which creates difficulties in obtaining a pure culture, identification and use of many strains. Besides, you must be sure that the selected endophyte will inhabit the internal plant tissues again and will have a positive effect. Another difficulty is the compatibility of endophytes isolated from one species of plants with plants of another species.

So, one of the innovative approaches recognized by the international experts as promising for an agricultural model under formation is the application of biologized technologies based on natural processes occurring in the soil - plant system. In this connection, plant-associated microorganisms and products of their metabolism are considered as a resource in the development of biotechnologies and their application for effective adaptation and rooting of microclones, as well as in plant protection. During the introduction of plant explants in aseptic culture, they are exposed to stress effects due to tissue damage and treatment with aggressive sterilizing agents, antibiotics, etc. This may be the cause of the sudden appearance of malicious endophytes during following passage. It is unclear until now what factor changes the nature of the interaction of an endophyte with its host, leading to the development of the pathological process instead of mutualistic relationship. The only way to control processes in such systems is the choice of the optimal passage time, optimal cultivation conditions and nutrient medium content to maintain mutualistic symbiosis beneficial for both the host plant and its endophytes.

\section{R E F E R E N C E S}

1. Prakash J. Micropropagation of ornamental perennials: progress and problems. Acta Horticulturae (ISHS), 2009, 812: 289-294 (doi: 10.17660/ActaHortic.2009.812.39).

2. Tailor J., H a r ri e r L. Beneficial influences of arbuscular micorrhizal fungi on the micropropagation of woody and fruit trees. In: Micropropagation of woody trees and fruits. Forestry sciences. V. 75. S.M. Jain, K. Ishii (eds.). Springer, Dordrecht, 2003: 129-150 (doi: 10.1007/97894-010-0125-0_5).

3. Klo e p p e r J.W., M c I n roy J.A., H u C.-H. Association of plant damage with increased populations of deleterious endophytes following use of Benlate systemic fungicide. Proc. 5th Int. Symp. «Endophytes for plant protection: the state of the art» (Humboldt University, Berlin, 26-29 May, 2013). C. Schneider, C. Leifert, F. Feldmann (eds.). Berlin-Dahlem, 2013: 56-69.

4. Cassels A.C. Doyle-Prestwi ch B. Detection and elimination of microbial endophytes and prevention of contamination in plant tissue culture. In: Plant tissue culture, development, and biotechnology. Boca Raton, 2011: 223-238 (doi: 10.1002/9780470054581.eib241).

5. Du na e va S.E., Os le dkin Yu.S. Bacterial microorganisms associated with the plant tissue culture: identification and possible role (review). Sel'skokhozyaistvennaya biologiya [Agricultural Biology], 2015, 50(1): 3-15 (doi: 10.15389/agrobiology.2015.1.3eng).

6. Kolomiets T.M., Malyarovskaya V.I., Gubaz S.L. Plodovodstvo $i$ yagodovodstvo 
Rossii, 2015, 43: 99-103 (in Russ.).

7. M a ly a rovsk y a V.I. Subtropicheskoe $i$ dekorativnoe sadovodstvo, 2012, 47(2): $161-167$ (in Russ.).

8. Samarina L.S. Optimizatsiya priemov mikrorazmnozheniya $i$ sokhraneniya limona in vitro. Kandidatskaya dissertatsiya. Moskva, 2013 (in Russ.).

9. Friesen M.L., P orter S.S., S tark S.C., von We t teberg E.J., S a c hs J.L., M a r t i ne z-Rome ro E. Microbially mediated plant functional traits. Annual Review of Ecology, Evolution, and Systematics, 2011, 42: 23-46 (doi: 10.1146/annurev-ecolsys-102710-145039).

10. Bulgarelli D., Schlaeppi K., Spaeten S., Ver Loren van Themaat E., $\mathrm{Schulze}-\mathrm{Lefert}$ P. Structure and functions of the bacterial microbiota of plants. Annu. Rev. Plant Biol., 2013, 64: 807-838 (doi: 10.1146/annurev-arplant-050312-120106).

11. Jacobs S., Zechmann B., Molitor A., Trujillo M., Petutschnig E., Lip $\mathrm{ka}$ V., K o g e $1 \mathrm{~K}$.-H., S c hä fer P. Broad-spectrum suppression of innate immunity is required for colonization of Arabidopsis roots by the fungus Piriformospora indica. Plant Physiol., 2011, 156: 726-740 (doi: 10.1104/pp.111.176446).

12. Partida-Martín e z L.P., H e i 1 M. The microbe-free plant: fact or artifact? Front. Plant Sci., 2011, 2: 100 (doi: 10.3389/fpls.2011.00100).

13. Provorov N.A., Vo ro b'e v N.I. Ekologicheskaya genetika, 2013, 11(1): 12-22 (in Russ.).

14. Brinkmann N., Marheine M., Heine-Dobbernack E., Verbarg S., Frühling A. S pröer C., Mohr K.I., S chu ma che r H.M. Investigation of latent bacterial infections in callus cultures reveal new Paenibacillus species. In: Endophytes for plant protection: the state of the art. Proc. 5th Int. Symp. «Endophytes for plant protection: the state of the art» (Humboldt University, Berlin, 26-29 May, 2013). C. Schneider, C. Leifert, F. Feldmann (eds.). Berlin-Dahlem, 2013: 10-11.

15. Kolomiets T.M., Malya rovskaya V.I., Gvasaliya M.V., S a mari na L.S., S o k olov R.N. Propagation in vitro of subtropical, ornamental crops and endemic species of western caucasus: developed and improved protocols. Sel'skokhozyaistvennaya biologiya [Agricultural Biology], 2014, 3: 49-58 (doi: 10.15389/agrobiology.2014.3.49eng).

16. Q i n S., Xing K., J i a ng J.H., X u L.H., Li W.J. Biodiversity, bioactive natural products and biotechnological potential of plant-associated endophytic actinobacteria. Appl. Microbiol. Biotechnol., 2011, 89(3): 457-473 (doi: 10.1007/s00253-010-2923-6).

17. Nowak J. Benefits of in vitro «biotization» of plant tissue cultures with microbial inoculants. In Vitro Cell. Dev. Biol. - Plant, 1998, 34: 122-130 (doi: 10.1007/BF02822776).

18. R a i M.K. Current advances in mycorrhization in micropropagation. In Vitro Cell. Dev. Biol. Plant, 2001, 37:158-167 (doi: 10.1079/IVP2000163).

19. K a p o o r R., S harma D., B hat nagar A.K. Arbuscular mycorrhizae in micropropagation systems and their potential applications. Science Horticulturae, 2008, 116: 227-239 (doi: 10.1016/j.scienta.2008.02.002).

20. J a n s a J., Vos at k a M. In vitro and post vitro inoculation of micropropagated Rhododendrons with ericoid mycorrhizaln fungi. Appl. Soil Ecol., 2000, 15: 125-136 (doi: 10.1016/S09291393(00)00088-3).

21. Akello J., Dubo is T., Gold C.S., Coyne D., Nakavuma J., Paparu P. Beauveria bassiana (Balsamo) Vuillemin as an endophyte in tissue culture banana (Musa spp.). J. Invertebr. Pathol., 2007, 96: 34-42 (doi: 10.1016/j.jip.2007.02.004).

22. Sha rma P., Kharkwal A.C., A b d i n M.Z., V a r m a A. Piriformospora indica improves micropropagation, growth and phytochemical content of Aloe vera L. plants. Symbiosis, 2014, 64: 11-23 (doi: 10.1007/s13199-014-0298-7).

23. Ting A.S.Y., M e on S., Kadir J., Radu S., Singh G. Endophytic microorganisms as potential growth promoters of banana. Bio Control, 2008, 53: 541-553 (doi: 10.1007/s10526-0079093-1).

24. Mucciarelli M., Scannerini S., Bertea C., Maffei M. In vitro and in vivo pepper-mint (Mentha piperita) growth promotion by nonmycorrhizal fungal colonization. New Phytologist, 2003, 158: 579-591 (doi: 10.1046/j.1469-8137.2003.00762.x).

25. Vohnik M., Lukan i S., Bahor E., Regvar M., Vosatka M., Vodnik D. Inoculation of Rhododendron cv. Belle-Heller with two strains of Phialocephala fortinii in two different substrates. Folia Geobotanica, 2003, 38: 191-200 (doi: 10.1007/BF02803151).

26. F ra n k e n P. The plant strengthening root endophyte Piriformospora indica: potential application and the biology behind. Appl. Microbiol. Biot., 2012, 96: 1455-1464 (doi: 10.1007/s00253012-4506-1).

27. Mayerhofer M.S., Kernaghan G., Harper K.A. The effects of fungal root endophytes on plant growth: a meta-analysis. Mycorrhiza, 2012, 23: 119-128 (doi: 10.1007/s00572012-0456-9).

28. A z li n C.O., A m ir H.G., C han La i K., Z a m z u ri I. Effect of plant growth-promoting rhizobacteria on root formation and growth of tissue cultured oil palm (Elaeis guineensis Jacq.). Biotechnology, 2007, 6: 549-554 (doi: 10.3923/biotech.2007.549.554).

29. B e n s o n A., Jo e M.M., Karthike yan B., S a T., Rajas e karan C. Role of Achro- 
mobacter xylosoxidans AUM54 in micropropagation of endangered medicinal plant Naravelia zeylanica (L.) DC. J. Plant Growth Regul., 2014, 33: 202-213 (doi: 10.1007/s00344-013-9363-3).

30. Larraburu E.E., L lo re nte B.E. Anatomical changes induced by Azospirillum brasilense in in vitro rooting of pink lapacho. Plant Cell Tiss. Organ Cult., 2015, 122: 175-184 (doi: 10.1007/s11240-015-0759-6).

31. Larraburu E.E., Carletti S.M., Rodriguez Caceres E.A., Llorente B.E. Micropropagation of photinia employing rhizobacteria to promote root development. Plant Cell Rep., 2007, 26: 711-717 (doi: 10.1007/s00299-006-0279-2).

32. Vestberg M., Kukkonen S., Saari K., Parikka P., Huttunen J., Tainio L., Devos N., Weekers F., Kevers C., Thonart P., Lemoine M.C., Cordier C., Alabouvette C., Gianinazzi S. Microbial inoculation for improving the growth and health of micropropagated strawberry. Appl. Soil Ecol., 2004, 27: 243-258 (doi: 10.1016/j.apsoil.2004.05.006).

33. Trivedi P., P a n d e y A. Biological hardening of micropropagated Picrorhiza kurrooa Royel ex Benth., an endangered species of medical importance. World Journal of Microbiology and Biotechnology, 2007, 23: 877-878 (doi: 10.1007/s11274-006-9293-3).

34. Ait Barka E.A., B elarbi A., Hachet C., Nowak J., Audran J.C. Enhancement of in vitro growth and resistance to gray mould of Vitis vinifera co-cultured with plant growthpromoting rhizobacteria. FEMS Microbiol. Lett., 2000, 186: 91-95 (doi: 10.1111/j.15746968.2000.tb09087).

35. Govindarajan M., Balandreau J., Muthukumarasamy R., Revathi G., $\mathrm{Laksh}$ min a-R a s m h n C. Improved yield of micropropagated sugarcane following inoculation by endophytic Burkholderia vietnamiensis. Plant Soil, 2006, 280: 239-252 (doi: 10.1007/s11104-005-3223-2).

36. Mirza M.S., Ahmad W., Latif F., Haurat J., Bally R., Normand P., Malik K.A. Isolation, partial characterization and the effect of plant growth-promoting bacteria (PGPB) on micropropagated sugarcane in vitro. Plant Soil, 2001, 237: 47-54 (doi: 10.1023/A:1013388619231).

37. Wei C.-Y., Lin L., Luo L.-J., Xing Y.-X., Hu C.-J., Yang L.-T., Li Y.-R., An Q. Endophytic nitrogen-fixing Klebsiella variicola strain DX120E promotes sugarcane growth. Biol. Fertil. Soils, 2014, 50: 657-666 (doi: 10.1007/s00374-013-0878-3).

38. Quambusch M., Pirttila A.M., Tejesvi M.V., Winkelmann T., Bartsch M. Endophytic bacteria in plant tissue culture: differences between easy- and difficult-to-propagate Prunus avium genotypes. Tree Physiology, 2014, 34(5): 524-533 (doi: 10.1093/treephys/tpu027).

39. Thomas J., Ajay D., Raj Kumar R., Mandal A.K.A. Influence of beneficial microorganisms during in vivo acclimatization of in vitro-derived tea (Camellia sinensis) plants. Plant Cell Tiss. Organ Cult., 2010, 101: 365-370 (doi: 10.1007/s11240-010-9687-7).

40. Lifshitz R., Kloepper J.W., Kozlowski M., S imonson C., Carlson J., Tip p ing E.M., Z a leska I. Growth promotion of canola (rapeseed) seedlings by a strain of Pseudomonas putida under gnotobiotic conditions. Can. J. Microbiol., 1987, 33: 390-395 (doi: 10.1139/m87-068).

41. Ovando-Medina I., Adriano-Anaya L., Chávez-Aguilar A., Oliva-Llave A., Ayora-Talavera T., Dendooven L., Gutierrez-Miceli F., Salvad o r-Fig u e roa M. Ex vitro survival and early growth of Alpinia purpurata plantlets inoculated with Azotobacter and Azospirillum. Pakistan Journal of Biological Sciences, 2007, 10: $3454-$ 3457 (doi: 10.3923/pjbs.2007.3454.3457).

42. Nowak J., Shula ev V. Priming for transplant stress resistance in in vitro propagation. In Vitro Cell. Dev. Biol. - Plant, 2003, 39: 107-124 (doi: 10.1079/IVP2002403).

43. Harish S., Kavino M., Kumar N., Saravanakumar D., Soorianathasunda ram K., S a mi y p pa n R. Biohardening with plant growth promoting rhizosphere and endophytic bacteria induces systemic resistance against Banana bunchy top virus. Appl. Soil Ecol., 2008, 39: 187-200 (doi: 10.1016/j.apsoil.2007.12.006).

44. $\mathrm{Z}$ a b e t a k is I. Enhancement of flavour biosynthesis from strawberry (Fragaria $\times$ ananassa) callus cultures by Methylobacterium species. Plant Cell Tiss. Organ Cult., 1997, 50: 179-183 (doi: 10.1023/A:1005968913237).

45. Ortiz-Castro R., Contreras-Cornejo H., Macias-Rodriguez L., LopezB u c i o J. The role of microbial signals in plant growth and development. Plant Signaling \& Behavior, 2009, 4: 701-712 (doi: 10.4161/psb.4.8.9047).

46. Compant D., Duffy B., Nowak J., Cléme nt C., B a rka E.A. Use of plant growthpromoting bacteria for biocontrol of plant diseases: principles, mechanisms of action, and future prospects. Appl. Environ. Microbiol., 2005, 71: 4951-4959 (doi: 10.1128/AEM.71.9.4951-4959.2005).

47. Sziderics A.H., Rasche F., Trognitz F., Sessitsch A., Wilhe $1 \mathrm{~m} \mathrm{E.} \mathrm{Bacterial}$ endophytes contribute to abiotic stress adaptation in pepper plants (Capsicum annuum L.). Can. J. Microbiol., 2007, 53: 1195-1202 (doi: 10.1139/W07-082). 
48. Li n L, X u X.D. Indole-3-acetic acid production by endophytic Streptomyces sp. En-1 isolated from medicinal plants. Curr. Microbiol., 2013, 67(2): 209-217 (doi: 10.1007/s00284-013-0348-z).

49. I g a ras h i Y. Screening of novel bioactive compounds from plant-associated actinomycetes. Actinomycetologica, 2004, 18: 63-66 (doi: 10.3209/saj.18_63).

50. R a sh ad F.M., F a thy H.M., E $1-\mathrm{Z}$ ay at A.S., E $1 \mathrm{~g}$ ho $\mathrm{n}$ a imy A.M. Isolation and characterization of multifunctional Streptomyces species with antimicrobial, nematicidal and phytohormone activeiekhties from marine environments in Egypt. Microbiol. Res., 2015, 175: 34-47 (doi: 10.1016/j.micres.2015.03.002).

51. S o u s a J., O liva res F.L. Plant growth promotion by streptomycetes: ecophysiology, mechanisms and applications. Chemical and Biological Technologies in Agriculture, 2016, 3: 24 (doi: 10.1186/s40538-016-0073-5).

52. N o r m and L., Bärts chi H., D e baud J.C., G a y G. Rooting and acclimatization of micropropagated cuttings of Pinus pinaster and Pinus sylvestris are enhanced by the ectomycorrhizal fungus Hebeloma cylindrosporum. Physiologia Plantarum, 1996, 98: 759-766 (doi: 10.1111/j.1399-3054.1996.tb06682).

53. Oliveira P., B a rriga J., Cavaleiro C., Peixe A., P otes A.Z. Sustained in vitro root development obtained in Pinus pinea L. inoculated with ectomycorrhizal fungi. Forestry, 2003, 76(5): 579-587 (doi: 10.1093/forestry/76.5.579).

54. Blaha D., Prigent-Combaret C., Mirza M.S., Moenne-Loccoz Y. Phylogeny of the 1-aminocyclopropane-1-carboxylic acid deaminase-encoding gene acdS in phytobeneficial and pathogenic Proteobacteria and relation with strain biogeography. FEMS Microbiol. Ecol., 2005, 56: 455-470 (doi: 10.1111/j.1574-6941.2006.00082.x).

55. Zawadzka M., Trzciński P., Nowak K., Orlikowska T. The impact of three bacteria isolated from contaminated plant cultures on in vitro multiplication and rooting of microshoots of four ornamental plants. Journal of Horticultural Research, 2013, 21(2): 41-51 (doi: 10.2478/johr-2013-0020).

56. Grotkas s C., Hutter I., Fe ld mann F. Use of arbuscular mycorrhizal fungi to reduce weaning stress of micropropagated Baptisia tinctoria (L.) R. BR. Acta Hort. (ISHS), 2000, 530: 305-312.

57. B a rka E.A., Gognies S., Nowak J., A ud ra n J.-C., B e la rbi A. Inhibitory effect of endophytic bacteria on Botrytis cinerea and its influence to promote the grapevine growth. Biol. Control, 2002, 24: 135-142 (doi: 10.1016/S1049-9644(02)00034-8).

58. Kh a os a d T., García-Garrido J.M., Steinkellner S., Vie rheilig H. Takeall disease is systemically reduced in roots of mycorrhizal barley plants. Soil Biol. Biochem., 2007, 39: 727-734 (doi: 10.1016/j.soilbio.2006.09.014).

59. I s t if a d a h N., M c G e e P.A. Endophytic Chaetomium globosum reduces development of tan spot in wheat caused by Pyrenophora triticirepentis. Australasian Plant Pathology, 2006, 35: 411418 (doi: 10.1071/AP06038).

60. K o c zwara K., Pańk a D., J eske M, M usiał N. Effect of Neotyphodium lolii on production of $\beta$-1,3-glucanases and chitinases in perennial ryegrass (Lolium perenne L.) infected by Fusarium poae. In: Endophytes for plant protection: the state of the art. Proc. 5th Int. Symp. «Endophytes for plant protection: the state of the art» (Humboldt University, Berlin, 26-29 May, 2013). C. Schneider, C. Leifert, F. Feldmann (eds.). Berlin-Dahlem, 2013: 123-124.

61. S i ng h L.P., G i 11 S.S., T u t e ja N. Unraveling the role of fungal symbionts in plant abiotic stress tolerance. Plant Signaling \& Behavior, 2011, 6(2): 175-191 (doi: 10.4161/psb.6.2.14146).

62. Moham mad M.J., Malkawi H.I., Shibli R. Effects of arbuscular mycorrhizal fungi and phosphorus fertilization on growth and nutrient uptake of barley grown on soils with different levels of salts. J. Plant Nutr., 2011, 26: 125-137 (doi: 10.1081/PLN-120016500).

63. Eve li n H., K a p o o r R., G i r i B. Arbuscular mycorrhizal fungi in alleviation of salt stress: a review. Annals of Botany, 2009, 104(7): 1263-1280 (doi: 10.1093/aob/mcp251).

64. H a rdoim P.R., van Overbeek L.S., B erg G., Pirttilä A.M., Compant S., $\mathrm{C}$ a m p is a no A., Döring M., S e s sits ch A. The hidden world within plants: ecological and evolutionary considerations for defining functioning of microbial endophytes. Microbiol. Mol. Biol. Rev., 2015, 79: 293-320 (doi: 10.1128/MMBR.00050-14).

65. Abbamondi G.R., Tommonaro G., Weyens N., Thijs S., Sillen W., Gkore Z i s P., I o d i c e C., Rangel W.M., Nicolaus B., Vangronsveld J. Plant growthpromoting effects of rhizospheric and endophytic bacteria associated with different tomato cultivars andnew tomato hybrids. Chemical and Biological Technologies in Agriculture, 2016, 3(1): 110 (doi: 10.1186/s40538-015-0051-3).

66. Bonaldi M., Chen X., Kunova A., Pizzatti C., Saracchi M., Cortesi P. Colonization of lettuce rhizosphere and roots by tagged Streptomyces. Front. Microbiol., 2015, 6: 25 (doi: doi: 10.3389/fmicb.2015.00025).

67. Francis I., Holsters M., Veree cke D. The Gram-positive side of plantmicrobe interactions. Environ. Microbiol., 2010, 12(1): 1-12 (doi: 10.1111/j.1462-2920.2009.01989.x).

68. Nebbioso A., De Martino A., Eltlbany N., Smalla K., Piccolo A. Phytochemical profiling of tomato roots following treatments with different microbial inoculants as 
revealed by IT-TOF mass spectrometry. Chemical and Biological Technologies in Agriculture, 2016, 3(1): 1-8 (doi: 10.1186/s40538-016-0063-7).

69. Sessitsch A.1., Hardoim P., Döring J., Weilharter A., Krause A., Woyke T., Mitter B., Hauberg-Lotte L., Friedrich F., Rahalkar M., Hurek T., Sarkar A., Bodrossy L., van Overbeek L., Brar D., van Elsas J.D., Reinhold-Hurek B. Functional characteristics of an endophyte community colonizing rice roots as revealed by metagenomic analysis. Mol. Plant-Microbe Interact., 2012, 25: 28-36 (doi: 10.1094/MPMI-08-11-0204).

70. Bulgari D., Casati P., Crepaldi P., Daffonchio D., Quaglino F, Brusetti L., B i a n c o P.A.. Restructuring of endophytic bacterial communities in grapevine yellows-diseased and recovered Vitis vinifera L. plants. Appl. Environ. Microbiol., 2011, 77: 5018-5022 (doi: 10.1128/AEM.00051-11).

71. Campisano A., Antonielli L., Pancher M., Yousaf S., Pindo M., Pertot I. Bacterial endophytic communities in the grapevine depend on pest management. PLoS ONE, 2014: 9(11): e112763 (doi: 10.1371/journal.pone.0112763).

72. Klocke E., Weinzierl K., Abel S. Occurrence of endophytes during Pelargonium protoplast culture. In: Endophytes for plant protection: the state of the art. Proc. 5th Int. Symp. «Endophytes for plant protection: the state of the art» (Humboldt University, Berlin, 26-29 May, 2013). C. Schneider, C. Leifert, F. Feldmann (eds.). Berlin-Dahlem, 2013: 94-99. 